\title{
The Use of the Jigsaw Cooperative Learning Model as an Effort to Improve the Writing Skills of Knowledge Book Review for Class IX A Students of SMP Negeri 1 Padamara Odd Semester Academic Year 2018/2019
}

\author{
Untung Pujiarto ${ }^{1, a)}$ \\ 1 \\ SMP Negeri 1 Padamara, Kabupaten Purbalingga, Jawa Tengah, Indonesia \\ E-mail: a) pujiartountung69@yahoo.com
}

\begin{abstract}
This study aims to describe the skills of writing a book review of knowledge based on the completeness and accuracy of the review element, the language used, the use of spelling, and punctuation. for IXA grade students of SMP Negeri 1 Padamara odd semester 2018/2019 using the jigsaw type cooperative learning model. The approach used in this study is a qualitative research approach with a class action research design. This research was designed through classroom action research conducted in the form of an action cycle. This research was conducted in September 2018 until December 2018 in Class IXA of SMP Negeri 1 Padamara. Research data obtained from interactions between teacher and student, student and student and student teacher during the learning process. Data collection activities carried out by the method of observation, interviews, and documentation. Data analysis was performed with flow analysis which included (1) data reduction (2) data presentation, (3) drawing conclusions / verification, (4) data reflection, and (5) reflection of research findings. Research results both in terms of process and results. Writing learning can be concluded that the type of jigsaw cooperative learning model can improve the writing skills of knowledge book review in learning writing in class IXA SMP Negeri 1 Padamara odd semester of the 2018/2019 academic year.
\end{abstract}

Keyword: review writing skills, jigsaw type

\begin{abstract}
Abstrak
Penelitian ini bertujuan untuk mendeskripsikan keterampilan menulis resensi buku pengetahuan berdasarkan kelengkapan dan ketepatan unsur resensi, bahasa yang digunakan, penggunaan ejaan, dan tanda baca. bagi siswa kelas IXA SMP Negeri 1 Padamara semester gasal tahun pelajaran 2018/2019 dengan menggunakan model pembelajaran kooperatif tipe jigsaw. Pendekatan yang digunakan dalam penelitian ini
\end{abstract}


adalah pendekatan penelitian kualitatif dengan rancangan penelitian tindakan kelas. Penelitian ini dirancang melalui penelitian tindakan kelas yang dilaksanakan dalam bentuk siklus tindakan. Penelitian ini dilaksanakan pada September 2018 sampai dengan Desember 2018 di Kelas IXA SMP Negeri 1 Padamara. Data penelitian diperoleh dari interaksi antara guru dan siswa, siswa dengan siswa dan siswa guru selama pembelajaran berlangsung. Kegiatan pengumpulan data dilakukan dengan metode pengamatan, wawancara, dan dokumentasi. Analisis data dilakukan dengan analisis mengalir yang mencakup (1) reduksi data (2) sajian data, (3) penarikan simpulan/ verifikasi, (4) refleksi data, dan (5) refleksi temuan penelitian. Hasil penelitian baik dari segi proses maupun hasil. Pembelajaran menulis tersebut dapat disimpulkan bahwa model pembelajaran kooperatif tipe jigsaw dapat meningkatkan keterampilan menulis resensi buku pengetahuan dalam pembelajaran menulis di kelas IXA SMP Negeri 1 Padamara semester gasal tahun pelajaran 2018/2019.

Kata kunci: keterampilan menulis resensi, tipe jigsaw

\section{PENDAHULUAN}

Keterampilan berbahasa dalam kurikulum di sekolah mencakup empat segi, yaitu (1) keterampilan menyimak atau mendengarkan, (2) keterampilan berbicara,(3) keterampilan membaca, dan(4) keterampilan menulis. Setiap keterampilan tersebut erat sekali berhubungan dengan tiga keterampilan lainnya dengan cara yang beraneka ragam.

Keterampilan menulis seseorang ditunjukkan oleh kemampuannya menuangkan gagasan secara terorganisasi dengan baik melalui tulisan. Dengan kata lain, keterampilan menulis adalah kemampuan mengorganisasikan pikiran secara sistematis dan logis, baik dalam bentuk tulisan nonilmiah maupun tulisan ilmiah (Purwahida, 2018). Keterampilan menulis adalah keterampilan yang paling kompleks, karena keterampilan menulis merupakan suatu proses perkembangan yang menuntut pengelaman, waktu, kesepakatan, latihan serta memerlukan cara berpikir yang teratur untuk mengungkapkannya dalam bentuk bahasa tulis (Kusmayati, 2019). Oleh karena itu, kegiatan ini perlu mendapatkan perhatian guru secara sungguh-sungguh untuk memberikan bimbingan dan latihan secara teratur dan terarah, dengan demikian siswa diharapkan dapat mengetahui pola dan cara mengarang (Kusmana, 2014). Menurut Dalman (2015) ringkasan berarti merangkum bahan yang panjang menjadi sedikit mungkin. Namun yang sedikit itu dapat mewakili atau menjelaskan yang panjang. Jadi, secara umum dapat disimpulkan bahwa tujuan meringkas adalah memahami dan mengetahui isi sebuah buku atau karangan.

Kemampuan menulis resensi buku pengetahuan siswa kelas IXA SMP Negeri 1 Padamara semester gasal tahun pelajaran 2018/2019 masih rendah. Rendahnya kemampuan siswa tersebut ditandai dengan (1) frekuensi kegiatan menulis resensi yang dilakukan siswa sangat rendah, (2) kualitas karya tulis siswa buruk, (3) rendahnya antusiasme siswa dalam mengikuti pembelajaran menulis resensi, dan (4) rendahnya kreativitas siswa pada saat kegiatan pembelajaran menulis resensi berlangsung. Rendahnya keterampilan siswa dalam menulis resensi disebabkan oleh beberapa faktor yang turut mempengaruhi, di antaranya faktor ketepatan guru dalam memilih dan menerapkan metode pembelajaran. 
Menulis resensi merupakan salah satu kompetensi dasar mata pelajaran bahasa Indonesia yang harus dimiliki oleh peserta didik SMA (BSNP 2006). Akan tetapi, kenyataan di lapangan kemampuan menulis resensi peserta didik masih rendah. Kesulitan tersebut tampak pada ketidaktahuan peserta didik tentang apa yang harus ditulis dalam resensi dan bagaimana format penulisan resensi. Jika dibandingkan dengan keterampilan berbahasa yang lain (menyimak, berbicara, dan membaca), menulis lebih sulit dikuasai.

Pada pembelajaran materi menulis resensi buku pengetahuan yang terjadi di kelas IX A SMP Negeri 1 Padamara semester gasal tahun pelajaran 2018/2019 selama ini ditemukan bahwa pembelajaran bahasa Indonesia pada kompetensi dasar menulis resensi buku pengetahuan kurang meningkatkan kreativitas siswa, hal ini ditunjukkan dengan lebih banyak mengajarkan teori-teori, (2) fakta-fakta dan masalah-masalah yang diajar-kan guru dengan metode ceramah, (3) kurangnya partisipasi aktif siswa dalam mengikuti pelajaran,(4) siswa hanya mendengarkan, mencatat dan menghafalkannya saja, (5) prestasi siswa sangat kurang, hal ini dapat dilihat dari hasil belajar anak kurang dari 75\% mencapai nilai Kriteria Ketuntasan Minimal (KKM).

Dari hasil observasi ditemukan enam penyebab sebagai berikut: (1) guru kurang bervariasi dalam penggunaan model pembelajaran menulis resensi, (2) kompetensi guru dalam menulis resensi masih kurang, (3) proses kegiatan belajar mengajar yang kurang menarik perhatian siswa, (4) guru hanya menerangkan secara monoton tanpa memperhatikan keadaan siswa, (5) siswa hanya mengikuti ceramah guru, (6) siswa kurang menguasai cara menulis resensi yang benar.

Sehubungan dengan permasalahan yang dikemukakan di atas, maka peneliti menganggap bahwa hal tersebut perlu diatasi. Oleh karena itu, diperlukan model yang tepat dan mampu mengarahkan siswa untuk mengalami sendiri proses pembelajaran dengan pengalaman yang bermakna. Menurut Hamalik (2010), mengemukakan bahwa pembelajaran yang berkualitas sangat tergantung dari motivasi pelajar dan kreatifitas pengajar. Pembelajar yang memiliki motivasi tinggi ditunjang dengan pengajar yang mampu memfasilitasi motivasi tersebut akan membawa pada keberhasilan pencapaian target belajar. Target belajar dapat diukur melalui perubahan sikap dan kemampuan siswa melalui proses belajar. Model pembelajaran yang baik, ditunjang fasilitas yang memandai, ditambah dengan kreatifitas guru akan membuat peserta didik lebih mudah mencapai target belajar Guru yang kreatif harus memberikan model tentang tahapantahapan menulis dan membimbing siswa untuk mengalaminya sendiri. Siswa akan memperoleh kemampuan menulis apabila berlatih secara sistematis dalam proses dan dilakukan terus menerus (Purwahida, 2017; Chadis, 2019). Oleh karena itu, proses menulis sangat penting dibelajarkan kepada siswa. Namun, itu hanya akan diperoleh apabila adanya bimbingan guru secara langsung, praktik terarah, dan berbagai aplikasi mandiri (Eanes, 1997).

Secara umum, tahapan menulis meliputi tahap pramenulis, pengedrafan, dan merevisi. Pentahapan menulis itu dibagi menjadi empat tahap, yaitu (1) pramenulis, (2) menulis dan mendapatkan umpan balik dari draf awal, (3) melakukan revisi dan menulis kembali draf, dan (4) menyunting dan menulis draf akhir (Eanes, 1997; Samad, 1997). Pengkondisian pembelajaran menulis resensi seperti uraian di atas, diperlukan pemilihan dan penerapan model pembelajaran yang relevan dengan pendekatan proses dalam kegiatan menulis. Salah satu model yang dapat diterapkan adalah model pembelajaran kooperatif tipe jigsaw. 
Pembelajaran kooperatif juga dikenal dengan pembelajaran secara berkelompok, belajar kelompok, kerja kelompok. Sehingga memungkinkan terjadinya interaksi secara terbuka hubungannya bersifat interdependensi efektif di antara anggota kelompok (Chotimah \& Dwitasari, 2009).

Pembelajaran kooperatif tipe Jigsaw merupakan salah satu tipe strategi pembelajaran yang kooperatif dan fleksibel (Desrina, 2013; Wahyuningsih, 2017). Dalam pembelajaran tipe Jigsaw, siswa dibagi menjadi kelompok-kelompok yang anggotanya mempunyai karakteristik heterogen. Masing-masing siswa bertanggung jawab untuk mempelajari topik yang ditugaskan dan mengajarkan pada anggota kelompoknya,sehingga mereka dapat saling berinteraksi dan saling bantu. Hal tersebut sama dengan hasil penelitian Soffalina (2010) yang menyatakan bahwa keunggulan pembelajaran kooperatif tipe Jigsaw adalah pembelajaran ini dapat meningkatkan rasa tanggung jawab siswa terhadap pembelajarannya sendiri dan juga pembelajaran orang lain serta dapat meningkatkan sikap kerja sama secara kooperatif untuk mempelajari materi yang ditugaskan. Riset yang berkaitan dengan pembelajaran kooperatif tipe Jigsaw banyak dilakukan salah satunya adalah pembelajaran kooperatif tipe Jigsaw terbukti dapat meningkatkan kemampuan akademik siswa.

Berdasarkan pada fokus penelitian tersebut, maka tujuan penelitian tindakan kelas ini secara umum adalah untuk meningkatan keterampilan menulis resensi buku pengetahuan siswa kelas IXA SMP Negeri 1 Padamara semester gasal tahun pelajaran 2018/2019 dengan menggunakan model pembelajaran kooperatif tipe jigsaw. Secara khusus tujuan penelitian ini adalah mendiskripsikan dua hal berikut. (1) Proses peningkatan pembelajaran keterampilan menulis resensi siswa Kelas IXA SMP Negeri 1 Padamara dengan menggunakan model pembelajaran kooperatif tipe jigsaw. (2) Hasil peningkatan keterampilan menulis resensi buku pengetahuan bagi siswa Kelas IXA SMP Negeri 1 Padamara dengan menggunakan model pembelajaran kooperatif tipe jigsaw.

Kegunaan penelitian ini ada dua yakni kegunaan teoritis dan kegunaan praktis. Kegunaan teoritis dari penelitian ini adalah dapat memberikan masukan pada pengembangan teori pembelajaran menulis resensi buku pengetahuan di SMP Negeri 1 Padamara dengan tipe jigsaw, sekaligus memberikan wawasan bagi pembaca tentang model pembelajaran kooperatif tipe jigsaw. Kegunaan praktis penelitian ini sebagai berikut. 1) Bagi guru bahasa Indonesia, memberikan alternatif solusi terhadap beberapa permasalahan yang timbul dalam pelaksanaan pembelajaran keterampilan menulis resensi buku pengetahuan di SMP terutama model pembelajaran kooperatif tipe jigsaw. Selain itu dapat juga memberikan masukan bagi para guru dalam pemanfaatan model pembelajaran kooperatif tipe jigsaw sebagai upaya untuk meningkatkan kualitas pembelajaran keterampilan menulis resensi buku pengetahuan sehingga anak mampu mengembangkan potensi yang dimilikinya. (2) Bagi siswa, penelitian ini setidaknya bisa memberikan stimulasi bagi anak dalam berpendapat, berfikir, dan berkreasi dalam meningkatkan kemampuan menulis resensi buku pengetahuan. Penggunaan tipe jigsaw dapat menyenangkan siswa sehinga akan mampu memotivasi siswa dalam belajar.

Rancangan PTK dipilih karena beberapa alasan di antarnya sebagai berikut. 1) Penelitian pembelajaran yang berkonteks kelas IXA SMP Negeri 1 Padamara semester gasal tahun pelajaran 2018/2019 dilaksanakan oleh guru untuk memecahkan masalahmasalah yang terdapat dalam proses pembelajaran termasuk pembelajaran menulis resensi. 2) Penelitian di kelas kelas IXA SMP Negeri 1 Padamara semester gasal tahun pelajaran 2018/2019 ini dilaksanakan untuk memperbaiki pembelajaran menulis resensi 
buku pengetahuan dan meningkatkan hasil belajar dengan alternatif pengelolaan kelas yang lebih konduktif dalam pembelajaran menulis resensi. 3) Bentuk kajian yang dilakukan di kelas IXA SMP Negeri 1 Padamara bersifat refleksif oleh guru untuk meningkatkan kemampuan rasional dalam melaksanakan tugas memperbaiki praktik pembelajaran dilakukan dalam konteks alamiah yaitu untuk mengkaji permasalahan faktual dalam pembelajaran keterampilan menulis resensi dengan menggunakan model pembelajaran kooperatif tipe jigsaw. 4) Penelitian di kelas IXA SMP Negeri 1 Padamara semester gasal tahun pelajaran 2018/2019 dilaksanakan secara kolaborasi dengan guru kelas dalam menyusun perencanaan, pelaksanaan dan pengambilan kesimpulan terhadap proses pembelalajaran menulis resensi dengan model pembelajaran kooperatif tipe jigsaw dilaksanakan berkelanjutan.

Sehubungan dengan hal tersebut di atas dapat dikemukakan bahwa rancangan penelitian tindakan kelas yang dilaksanakan dalam meningkatkan kemampuan menulis resensi di kelas IXA SMP Negeri 1 Padamara semester gasal tahun pelajaran 2018/2019 melalui tipe jigsaw akan dilaksanakan sesuai dengan karakteristik penelitian tindakan kelas. Penelitian tindakan kelas ini, penelitiannya berlangsung mulai dari pengamatan awal, perencanaan tindakan, pelaksanaan tindakan, observasi, dan refleksi. Penelitian dimulai pada bulan Desember 2018 sampai dengan Maret 2019, yang sebelumnya telah dilaksanakan pra penelitian. Sedangkan pelaksanaan penelitian dilakukan secara berkelanjutan untuk memperoleh data yang akurat.

Penelitian ini bersifat spesifik, penelitian ini dilakukan untuk meningkatkan kemampuan menulis resensi siswa kelas IXA SMP Negeri 1 Padamara semester gasal tahun pelajaran 2018/2019. Tidak dimaksudkan untuk melakukan generalisasi dan untuk memperoleh dalil-dalil. Penelitian ini bersifat unik, penelitian tindakan kelas memandang pembelajaran dari sudut pandang orang dalam yang tidak berjarak dengan peneliti yakni penelitian dilaksanakan oleh peneliti sekaligus sebagai pelaku pengajar bahasa Indonesia di kelas IXA SMP Negeri 1 Padamara semester gasal tahun pelajaran 2018/2019 dengan pelaksanaan bersama dengan kegiatan pembelajaran yang berlangsung seperti biasa tanpa mengubah jadwal. Penelitian ini bersifat kolaboratif, penelitian ini dilaksanakan bekerja sama dengan guru lain/ teman sejawat sebagai kolabolator dengan melaksanakan diskusi, observasi dari kondisi awal, menyusun perencanaan masuk bersama dalam kelas, memberi masukan pelaksanaan, mengamati pelaksanaan, membuat observasi, dan menilai jalannya kegiatan pembelajaran, melaksanakan refleksi menyampaikan kelebihan dan kekurangan selama kegiatan sehingga mampu mencapai tujuan penelitian. Penelitian ini bersifat kasuistik, karena berdasarkan hasil pengamatan awal siswa kelas IXA SMP Negeri 1 Padamara semester gasal tahun pelajaran 2018/2019 mengalami kasus kurang berhasil dalam pembelajaran menulis resensi, maka penelitian tindakan kelas yang akan dilaksanakan oleh peneliti adalah kasus pembelajaran menulis resensi siswa kelas IXA SMP Negeri 1 Padamara semester gasal tahun pelajaran 2018/2019. Penelitian ini hanya menggarap kasus pembelajaran menulis resensi yang dialami siswa kelas IXA SMP Negeri 1 Padamara. Penelitian berkonteks alamiah, dalam penelitian ini semua siswa kelas IXA SMP Negeri 1 Padamara semester gasal tahun pelajaran 2018/2019 yang berjumlah 32 siswa, penelitian ini akan menggunakan data-data yang akurat dan mencukupi untuk kepentingan penelitian, mulai tahap pengidentifikasian, pelaksanaan pelaporan demi tercapainya tujuan penelitian.

Berdasarkan karakteristik tersebut maka penelitian tindakan kelas ini dilaksanakan untuk meningkatkan kemampuan menulis resensi dengan model 
pembelajaran kooperatif tipe jigsaw. Penggunaan model pembelajaran ini dimaksudkan untuk mengatasi kesulitan siswa kelas IXA SMP Negeri 1 Padamara semester gasal tahun pelajaran 2018/2019 karena siswa mengalami kesulitan dalam menentukan sistematika menulis resensi, isi resensi yang meliputi penulisan identitas buku,latar belakang, keunggulan buku,kelemahan buku dan merumuskan nilai buku serta bahasa resensi yang meliputi penggunaan ejaan dan tanda baca, ketepatan pemilihan kata, pemilihan kalimat efektif yang digunakan sebagai prasarat penulisan resensi. Suharsimi (2007) menyatakan ciri khusus PTK adalah adanya tindakan yang nyata. Tindakan itu dilakukan pada situasi alami dan ditujukan untuk memecahkan permasalahanpermasalahan praktis. Tindakan tersebut adalah merupakan rencana kegiatan yang sengaja dilakukan dengan tujuan tertentu.

\section{METODE PENELITIAN}

Penelitian ini menggunakan pendekatan kualitatif dengan jenis rancangan penelitian tindakan kelas (PTK). Pada penelitian tindakan, kegiatan dilakukan dalam rangkaian siklus (Arikunto, 2010). Maka penelitian tindakan kelas ini direncanakan melalui beberapa tahap yang berlangsung dalam bentuk siklus sesuai dengan model yang dikembangkan yang menjelaskan tahap penelitian tindakan kelas dimulai dari perencanaan (planning), pelaksanaan tindakan (actuating), pengamatan (observating), dan refleksi (reflection). Model ini pada hakikatnya berupa untaian-untaian dengan satu perangkat terdiri dari empat komponen, yaitu perencanaan tindakan, pelaksanaan, pengamatan, dan refleksi. Empat kegiatan tersebut merupakan kegiatan yang dilaksanakan dalam satu siklus. Namun apabila pada siklus pertama belum menunjukkan peningkatan yang signifikan akan dilanjutkan pada siklus kedua dan seterusnya sampai usaha peningkatan kemampuan menulis resensi buku pengetahuan bagi siswa kelas IXA SMP Negeri 1 Padamara semester gasal tahun pelajaran 2018/2019 tercapai.

Berdasarkan siklus 1, jika penelitian di kelas IXA SMP Negeri 1 Padamara semester gasal tahun pelajaran 2018/2019 sudah mencapai KKM yang telah ditentukan, maka penelitian bisa dihentikan karena peneliti sudah dapat melakukan penyimpulam dari data yang diperoleh. akan tetapi jika penelitian berdasarkan siklus 1 belum berhasil memenuhi KKM yang telah ditentukan, maka penelitian akan diulang lagi dalam beberapa kali putaran, masing-masing putaran dikenakan perlakuan yang sama (alur kegiatan yang sama) dan membahas satu sub kompetensi dasar yang diakhiri dengan tes formatif di akhir masing-masing putaran. Dibuat dalam beberapa kali putaran dimaksudkan untuk memperbaiki sistem pengajaran yang telah dilaksanakan sampai sesuai dengan yang diinginkan atau nilai siswa telah memenuhi KKM yang telah ditentukan Penelitian dilakukan untuk meningkatkan kemampuan menulis resensi buku pengetahuan dengan model pembelajaran kooperatif tipe jigsaw pada siswa kelas IXA SMP Negeri 1 Padamara semester gasal tahun pelajaran 2018/2019 Penggunaan model pembelajaran kooperatif tipe jigsaw tersebut bertujuan untuk mengatasi masalah pembelajaran, yaitu rendahnya kemampuan menulis resensi buku pengetahuan siswa kelas IXA SMP Negeri 1 Padamara. Rencana penelitian tindakan kelas akan dilaksanakan sebanyak dua siklus.

Tempat penelitian adalah tempat yang digunakan dalam melakukan penelitian untuk memperoleh data yang diinginkan peneliti. Penelitian ini bertempat di SMP 
Negeri 1 Padamara khususnya di kelas IXA. Pemilihan SMP Negeri 1 Padamara sebagai tempat penelitian didasarkan beberapa pertimbangan antara lain, (1) peneliti mengajar di Kelas IXA SMP Negeri 1 Padamara, (2) jumlah siswa 32 orang dan kelas IXA SMP Negeri 1 Padamara semester gasal tahun pelajaran 2018/2019 mengalami kesulitan menulis resensi, (3) penggu-naan teknik jigsaw dalam menulis resensi cerpen belum pernah dilaksanakan dalam pembelajaran, (4) penelitian model pembelajaran kooperatif tipe jigsaw dalam KD menulis resensi belum pernah dilaksanakan, sehingga hasilnya diharapkan dapat memberikan manfaat untuk peningkatan pembelajaran di kelas IXA SMP Negeri 1 Padamara semester gasal tahun pelajaran 2018/2019.

Subjek penelitian adalah siswa kelas IXA SMP Negeri 1 Padamara semester gasal tahun pelajaran 2018/2019, berjumlah 32 siswa 22 perempuan 11 laki-laki. Seluruh siswa dilibatkan dalam kegiatan penelitian, karena mengikuti konteks alamiah pada proses pembelajaran yang sesungguhnya. Pertimbangan pemilihan kelas IXA SMP Negeri 1 Padamara ini karena peneliti mengajar di kelas ini. Berdasarkan survey awal ini memperoleh nilai yang tidak tuntas pada pembelajaran menulis, khususnya dalam menulis resensi buku yang KKM KD 4.2 telah dirumuskan berdasarkan kompleksitas, sumber daya dukung, dan intake siswa adalah 7.5, dan letak kesalahan yang sering dilakukan siswa pada kesempurnaan menulis resensi buku pengetahuan yang meliputi identitas buku,latar belakang/ kepengarang-an, keunggulan buku, kelemahan buku/ kesimpulan.

Persiapan penelitian tindakan kelas meliputi kegiatan pengidentifikasian masalah yang terdapat di kelas IXA SMP Negeri 1 Padamara semester gasal tahun pelajaran 2018/2019, penganalisaan tingkat keseriusan masalah, pemilihan masalah yang dipecahkan, dan penetapan kriteria keberhasilan pemecahan masalah yang dipilih. Dengan demikian, penelitian tindakan kelas senantiasa diawali dengan penelitian awal (preleminary studies). Pada penelitian ini tindakan awal dilakukan secara kolaboratif peneliti dan guru di kelas IXA SMP Negeri 1 Padamara semester gasal tahun pelajaran 2018/2019, Ibu Umi Rofikoh,S.Pd, di awal perencanaan tindakan. Untuk itu diperlukan kesiapan dari peneliti dan praktisi untuk menyamakan pemahaman dan penyikapan terhadap konsep pembelajaran menulis resensi dengan menggunanakan model pembelajaran kooperatif tipe jigsaw berupa bentuk dan contoh resensi. Pada tahap ini ada 4 kegiatan yang dilakukan yakni, (1) melakukan diskusi dengan guru yang mengajar bahasa Indonesia kelas IXA SMP Negeri 1 Padamara tentang materi pembelaran menulis resensi, (2) menetapkan rencana pembelajaran, (3) menetapkan pelaksanaan penilaian, (4) simulasi pembelajaran dan penilaian pada materi menulis resensi.

Pelaksanaan penelitian di Kelas IXA SMP Negeri 1 Padamara ini menjelaskan tentang jumlah putaran (cycle) yang dilaksanakan dalam rangka memecahkan masalah yang telah ditetapkan dengan masing-masing putaran terdiri dari tahap perencanaan (planning), pelaksanaan (implementasi), observasi (observation), dan refleksi (reflection).

Berdasarkan temuan permasalahan pada identifikasi awal, disusunlah rencana tindakan perbaikan dari masalah-masalah yang ditemui dalam proses pembelajaran menulis resensi buku. Penyusunan rencana tindakan ini berlandaskan pada prinsip kolaborasi antara peneliti dan guru bahasa Indonesia kelas IXA SMP Negeri 1 Padamara pada materi menulis resensi buku pengetahuan. Adapun langkah yang dilakukan adalah Pertama, peneliti dan guru menyusun silabus yang terdiri dari nama sekolah, mata pelajaran, kelas, semester, standar kompetensi, kompetensi dasar, materi pokok, kegiatan pembelajaran, indikator, penilaian alokasi waktu dan sumber belajar, 
dan rencana pelaksanaan pembelajaran dengan media model meliputi; (a) penetapan standar kompetensi, kompetensi dasar, indikator dan tujuan pembelajaran, (b) Menentukan materi atau bahan ajar, (c) menetapkan metode dan teknik pembelajaran, (d) menetukan media pembelajaran yakni penggunaan media model atau contoh resensi dari surat kabar, (e) Melakukan kegiatan pembelajaran yang berupa kegiatan pendahuluan, kegiatan inti dan penutup, dan (f) evaluasi pembelajaran. Kedua, menyusun indikator dan kriteria pencapaian siswa dalam pembelajaran dengan rubrik penilaian. Ketiga, menyusun pedoman pengamatan dan format pengamatan. Rencana kegiatan di atas disusun secara kolaboratif antara peneliti dan guru mata pelajaran bahasa Indonesia Kelas IXA SMP Negeri 1 Padamara. Hal ini sesuai dengan sifat penelitian tindakan kelas, yaitu bersifat kolaboratif partisipatoris. Praktisi perlu memahami secara komprehensif tentang strategi dan tindakan yang akan dilakukan. Kegiatan yang ditempuh sehubungan dengan maksud tersebut adalah melakukan diskusi antara peneliti dan praktisi tentang rencana tindakan dalam pembelajaran.

Pelaksanaan tindakan pada prinsipnya mengacu pada rencana yang telah ditetapkan. Pada kegiatan ini merupakan realisasi dari rencana tindakan dan dilakukan secara kolaboratif dengan guru bahasa Indonesia kelas IXA SMP Negeri 1 Padamara. Ada dua macam kegiatan yang dilakukan secara bersamaan antara guru dan peneliti yakni melaksanakan pembelajaran dan evaluasi pembelajaran. Fokus tindakan setiap siklus berupa implementasi model pembelajaran kooperatif tipe jigsaw dalam pembelajaran menulis resensi. Rencana tindakan pembelajaran dalam penelitian ini dilakukan dalam 2 siklus. Pada siklus pertama ditetapkan 2 kali pertemuan atau $2 \mathrm{x}$ ( $2 \times 40)$ menit, dan silklus kedua 1 kali pertemuan $(2 \times 40$ menit). Peneliti dan praktisi secara kolaboratif merencanakan kegiatan pembelajaran setiap siklusnya.

Observasi yang dilakukan pada penelitian di Kelas IXA SMP Negeri 1 Padamara ini menggunakan observasi sistematis artinya dilakukan oleh pengamat dengan menggunakan pedoman sebagai instrumen pengamat, bersamaan dengan pelaksanaan tindakan pembelajaran dengan tujuan untuk mendapatkan berbagai data yang diperlukan serta mengetahui kendala yang dihadapi guru dan siswa berkaitan dengan pembelajaran menulis resensi cerpen melalui model pembelajaran kooperatif tipe jigsaw. Dengan kata lain, kegiatan pengamatan ini dimaskudkan untuk mengenali, merekam, dan mendokumentasikan semua indikator (baik proses maupun hasil) yang terjadi sebagai akibat dari tindakan. Pada pelaksanaan tindakan, peneliti berkedudukan sebagai pengamat untuk memantau secara kritis dan objektif pelaksanaan pembelajaran serta untuk mengetahui kesesuaian antara perencanaan dengan pelaksanaan yang dilakukan oleh guru.

Untuk mendapatkan hasil pengamatan yang komprehensif, peneliti menggunakan instrumen pengumpul data yang telah dibuat sebelumnya. Pengamatan dilakukan mulai dari siklus pertama. Hasil pengamatan ini didiskusikan oleh peneliti dan praktisi secara kritis dan seksama, kemudian hasilnya diperlukan untuk kepentingan refleksi. Pengamatan yang dilakukan dalam satu siklus akan memberikan masukan dan dijadikan dasar bagi penyusunan rencana tindakan perbaikan pada siklus berikutnya. Berhasil tidaknya tindakan yang diberikan dapat dilihat dari hasil pengamatan setiap siklus. Data penelitian ini berupa data verbal dan nonverbal yang, bersumber dari tindakan dan hasil pembelajaran. Data diperoleh dari pengamatan awal, observasi, wawancara, refleksi, dan tulisan siswa. Dalam rangka mengumpulkan dan menganalisis data, penelitian tindakan kelas tentang peningkatan kemampuan menulis resensi cerpen siswa Kelas IXA SMP Negeri 1 Padamara ini menggunakan dua jenis instrumen, yakni 
(1) peneliti sebagai instrumen utama dan (2) beberapa lembar instrumen pendamping. Peneliti selaku instrumen utama atau instrumen kunci merupakan perencana tindakan, pengumpul data, penafsir data, dan pelapor hasil penelitian. Dengan demikian, peneliti selama tindakan di Kelas IXA SMP Negeri 1 Padamara berlangsung melakukan kegiatan-kegiatan, yakni; (1) mengadakan pengamatan awal tentang proses dan hasil pembelajaran menulis resensi cerpen, (2) bersama-sama menyusun rencana pembelajaran menulis resensi cerpen dengan menggunakan teknik Jigsaw (3) melihat, mengamati, dan mencatat aktivitas guru dan siswa pada saat pembelajaran berlangsung, (4) mengadakan wawancara dengan guru dan siswa setelah pembelajaran menulis dengan menggunakan model pembelajaran kooperatif tipe jigsaw, (5) menganalisis data verbal dan non-verbal yang diperoleh berdasarkan tahap-tahap penelitian tindakan kelas, dan (6) menyusun laporan seluruh proses dan hasil penelitian.

Beberapa instrumen pendamping yang digunakan sebagai penunjang kegiatan penelitian ini meliputi (1) lembar observasi, ( 2) lembar wawancara, dan ( 3) lembar evaluasi. Untuk pangambilan data yang mengukur kemampuan siswa dalam menulis resensi buku penulis menggunakan rubrik penilaian dengan fokus penilaian terdiri dari; penulisan identitas cerpen, penulisan latar belakng/kepengarangan, penulisan keunggulan buku, penulisan kelemahan buku dan merumuskan nilai buku/kesimpulan. Selanjutnya dari hasil kerja siswa yang berupa resensi, dinilai sesuai rubrik yang telah dibuat dalam tabel 3.1 dan memasukkan skor kedalam tabel 3.2, menjumlahkan skor, dan mengolahnya menjadi nilai akhir dengan rumus penghitungan jumlah skor yang diperoleh dibagi jumlah skor maksimal, lalu dikalikan 10.

Pengamatan dilakukan mulai dari siklus pertama sampai tercapai tujuan pembelajaran. Hasil pengamatan ini didiskusikan oleh peneliti dan praktisi secara kritis dan seksama, kemudian hasilnya diperlukan untuk kepentingan refleksi. Pengamatan yang dilakukan dalam satu siklus akan memberikan masukan dan dijadikan dasar bagi penyususunan rencana tindakan perbaikan pada siklus berikutnya. Berhasil tidaknya tindakan yang diberikan dapat dilihat dari hasil intepretasi pengamatan dan penilaian setiap siklus.

Pada akhir tindakan setiap tahap pembelajaran, dilakukan kegiatan refleksi. Dalam kegiatan ini, peneliti dan praktisi mendiskusikan dan membahas secara kritis dan seksama hasil-hasil pengamatan maupun data penunjang lainnya yang berkaitan dengan pembelajaran yang dilakukan. Hal-hal yang dibahas dan didiskusikan, yaitu (1) tindakan yang telah dilakukan, (2) perbedaan antara perencanaan tindakan dengan pelaksanaan tindakan yang telah dilakukan, (3) kendala-kendala yang ditemui dalam pelaksanaan pembelajaran dan mencari solusinya, dan (4) melakukan interprestasi, hasil pengamatan dalam pelaksanaan dan nilai siswa, dilanjutkan penyimpulan data yang diperoleh. Hasil refleksi ini memberi masukan bagi peneliti untuk menentukan sikap bagi pelaksanaan siklus berikutnya. Selain itu, hasil ini dijadikan dasar untuk menyusun rencana pembelajaran berikutnya sebagai tindakan perbaikan atau penyempurnaan pelaksanaan pembelajaran sebelumnya. Tindakan akan berhenti apabila telah mencacapai indikator hasil pembelajaran yang telah ditetapkan.

\section{HASIL DAN PEMBAHASAN}

Kemampuan menulis resensi buku kelas IXA SMP Negeri 1 Padamara sebelum tindakan kemampuan menulis resensi buju kelas IX A SMP Negeri 1 Padamara sebelum 
dilakukan tindakan terlihat dalam hasil tes awal. Dari hasil tes awal, peneliti menghitung nilai rata-rata setiap aspek untuk mengetahui kemampuan menulis resensi cerpen siswa sebelum dilakukan implementasi tindakan. Secara keseluruhan nilai ratarata kelas 6,7 dapat dikatakan masih di bawah standar Kriteria Ketuntasan Minimal (KKM) yaitu 72, sedangkan persentase ketuntasan secara klasikal 53,1\% atau ada 17 siswa dari 32 siswa yang sudah tuntas belajar. Hasil tersebut menunjukkan bahwa pada tes awal secara klasikal siswa belum tuntas belajar, karena siswa yang memperoleh nilai 72 hanya sebesar 53,1\% lebih kecil dari presentase ketuntasan klasikal (KKM) yang dikehendaki yaitu sebesar $75 \%$.

\section{Hasil Penelitian Siklus I}

Hasil penelitian pada siklus I meliputi (1) perencanaan tindakan, (2) pelaksanaan tindakan, (3) observasi tindakan, dan (4) refleksi tindakan Berdasarkan hasil refleksi dan diskusi antara peneliti dan guru bahasa Indonesia kelas IX A disimpulkan bahwa secara umum pembelajaran menulis resensi buku dengan menggunakan model pembelajaran kooperatif tipe jigsaw pada kegiatan inti telah berjalan cukup baik walaupun belum sepenuhnya memenuhi harapan sebagaimana mestinya. Catatan refleksi yang perlu dipertahankan yakni sebaiknya guru pada siklus I selalu menunjukan dan menyebutkan secara langsung identitas buku, keunggulan buku, kelemahan buku dan merumuskan nilai/kesimpulan buku serta kesalahan dalam penulisan latar belakang/kepengarangan buku sehingga memperkuat temuan pengetahuan konseptual siswa..

\section{Hasil Penelitian Siklus II}

Hasil penelitian pada siklus II meliputi (1) perencanaan tindakan, (2) pelaksanaan tindakan, (3) observasi tindakan, dan (4) refleksi tindakan. Secara umum keterampilan menulis resensi buku yang dilakukan siswa mengalami peningkatan dari perbandingan sebelum mendapat tindakan dengan setelah mendapat tindakan pada siklus I1, yaitu nilai rata-rata kelas 8,2 sebelum dilakukan tindakan dan memperoleh nilai rata-rata kelas 8,7 setelah dilakukan tindakan siklus 1, sehingga mengalami peningkatan pada siklus II sebesar 0,2. Selain itu keterampilan menulis resensi cerpen secara klasikal sudah mencapai Standar Kriteria Ketuntasan Minimal (KKM) 72 dari presentase ketuntasan (KKM) yang ditetapkan sebesar minimal 75\%., yaitu mengalami peningkatan dari perbandingan pada tindakan siklus I dengan setelah mendapat tindakan pada siklus II, hal ini ditunjukkan dengan siswa yang memperoleh nilai 75 mencapai ketuntasan belajar 78,1\% pada tindakan siklus I dan mencapai ketuntasan belajar 90,6\% setelah dilakukan tindakan siklus II atau terdapat 25 siswa dari 32 siswa yang sudah tuntas belajar. Berdasarkan hasil refleksi dan diskusi antara peneliti dan guru Bahasa Indonesia kelas IXA disimpulkan bahwa secara umum pembelajaran menulis resensi buku dengan model pembelajaran kooperatif tipe jigsaw pada kegiatan akhir pembelajaran siklus II telah berjalan dengan sangat baik.

Hasil temuan peneliti menunjukkan bahwa skenario pembelajaran menulis resensi buku dengan menggunakan model pembelajaran kooperatif teknik jigsaw berpusat pada aktivitas siswa. Sejalan dengan tujuan pembelajaran bahasa Indonesia di SMP, maka kegiatan pembelajaran berlangsung siswa di samping mengembangkan kemampuan tulisannya, juga dapat mengembangkan kemampuan lisannya. Kemampuan berkomunikasi tulis didapatkan melalui proses menulis resensi buku, sedangkan kemampuan komunikasi lisan diperoleh siswa melalui aktivitas diskusi pada expert 
group maupun home group dan tanya jawab di dalam kelas tentang berbagai unsur dan bagian tulisan resensi buku.

Hasil dan temuan penelitian menunjukan bahwa model pembelajaran kooperatif tipe jigsaw ini dapat dijadikan sebagai salah satu model pembelajaran menulis resensi buku di SMP dan kompetensi dasar lainnya. Penerapan strategi memiliki tiga karakteristik sebagai berikut. Pertama, pembelajaran dilaksanakan dengan menarik, bermakna, dan bervariasi. Hal ini tampak dari pemilihan topik dan pengembangan detail subtopik melalui formula jurnalistik. Perkembangan intelektualnya dapat berpikir efektif dan dapat menyatakan operasi mentalnya dengan simbol-simbol bahasa tulis berupa kata-kata dan kalimat untuk mewakili ide, perasaan, respon terhadap peristiwa atau objek, ataupun tanggapan-tanggapan terhadap berbagai hal. Dengan demikian, siswa SMP kelas IX dengan menulis resensi buku sudah dapat menuangkan isi atau ide pengarang yang dituangkan dalam sebuah buku atau dalam wujud tulisan resensi buku.

Sebagaimana telah dikemukakan dalam hasil temuan penelitian bahwa salah satu strategi yang berorientasi pada keaktifan siswa, pada masing-masing tahap pembelajaran menulis resensi buku, siswa melakukan suatu aktivitas yang terprogram mulai dari merumuskan masalah, menemukan jawaban sementara, mencari data, mengkaji temuan, sampai dengan menarik kesimpulan. Berkaitan dengan hal itu guru perlu menciptakan situasi pembelajaran partisipasif. Dalman (2015) mengemukakan ciri-ciri pembelajaran partisipasif, yakni: (1) mendorong siswa untuk siap belajar, (2) me mbantu siswa untuk mendiagnosis dan menemukan kebutuhan belajarnya, (3) membantu siswa untuk memahami tujuan belajarnya, (4) membantu siswa dalam melakukan kegiatan belajar, dan (5) membangun siswa melakukan evaluasi diri terhadap proses dan hasil belajar.

Dalam pelaksanaan pembelajaran menulis resensi buku siswa memiliki peran sentral sebagai subjek pelaku belajar. Keseluruhan tahapan pembelajaran menulis resensi buku memerlukan keaktifan dan kesungguhan siswa dalam belajar. Siswa mempelajari bahasa sebagai alat komunikasi, lebih daripada sekedar pengetahuan tentang bahasa. Karakteristik belajar siswa tercermin mulai dari kegiatan proses identifikasi unsur-unsur dan bagian-bagian rsensi buku, penentuan identitas cerpen, latar belakang/kepengarangan, keunggulan buku, kelemahan buku dan merumuskan nilai buku/kesimpulan, perevisian resensi cerpen. Perevisian sebagai salah satu tahapan menulis memiliki posisi yang strategis bagi keseluruhan proses pembelajaran. KTSP BI untuk SMP menyebutkan bahwa merevisi merupakan salah satu kompetensi yang dituntut di dalam daftar kompetensi dasar. Dengan demikian, siswa tidak semata-mata menggantungkan diri pada guru untuk memperbaiki tulisannya sendiri. Dalam proses perevisian siswa dapat saling menukarkan hasil dan saling memberikan saran atas tulisan resensi buku teman lainnya. Prinsip pembelajaran dalam KTSP mencantumkan pembelajaran hendaknya terpusat pada siswa dengan cara dilatih lebih banyak menggunakan bahasa untuk komunikasi, bukan dituntut lebih banyak menguasai pengetahuan tentang bahasa. Sejalan dengan hal ini strategi menjadi semakin relevan untuk diterapkan dalam pembelajaran menulis resensi buku di SMP. Siswa dalam hal ini memiliki kesempatan seluas-luasnya untuk terlibat secara aktif dan menyampaikan pengetahuan yang telah dimiliki sebelumnya. Guru bertindak sebagai fasilitator yang membimbing dan mengarahkan kegiatan belajar siswa dengan cara melakukan beberapa hal, yakni (1) mengobservasi proses menulis siswa, (2) mencatat dan mengecek seluruh hasil menulis siswa, (3) menyusun tugas dan latihan kelompok, (4) memberikan kesempatan khusus bagi siswa yang memiliki kemampuan berbeda dengan yang lain, 
(5) mempelajari hasil refleksi diri siswa dalam menulis, dan (6) melakukan penilaian secara adil dan terbuka. Relevansi Temuan Penelitian dengan Media/Sarana Pembelajaran Bahasa Indonesia di SMP Hasil dan temuan penelitian menunjukkan bahwa media dan sarana pembelajaran menulis resensi cerpen, yaitu (1) contoh resensi buku, dan (2) buku teks Bahasa Indonesia kelas Kelas IX untuk SMP. Tujuan penggunaan kedua jenis media dan sarana tersebut, yakni untuk mempermudah siswa mendapatkan dan menemukan berbagai informasi teoritis maupu praktis tentang tulisan resensi buku. Informasi ini berubah menjadi pengetahuan dan pengalaman baru siswa setelah seluruh rangkaian pembelajaran telah selesai dilaksanakan. Secara umum keterampilan menulis resensi buku yang dilakukan siswa memperoleh peningkatan ratarata yang signifikan pada tindakan siklus I dan II. Selain itu keterampilan menulis resensi buku secara klasikal sudah mencapai lebih dari Kriteria Ketuntasan Minimal (KKM) 72 dari presentase ketuntasan (KKM) yang ditetapkan sebesar minimal $75 \%$, yaitu mengalami peningkatan dari perbandingan pada tindakan siklus I dengan setelah mendapat tindakan pada siklus II, hal ini ditunjukkan dengan siswa yang memperoleh nilai 72 mencapai ketuntasan belajar $78,1 \%$ pada tindakan siklus I dan mencapai ketuntasan belajar 90,6\% setelah dilakukan tindakan siklus II atau terdapat 25 siswa untuk siklus I dan 29 siswa untuk siklus II yang sudah tuntas belajar dari 32 jumlah siswa. Dengan demikian dapat disimpulkan bahwa tindakan model pembelajaran kooperatif tipe Jigsaw berhasil diterapkan pada mata pelajaran bahasa Indonesia.

\section{KESIMPULAN}

Secara umum dapat disimpulkan bahwa keterampilan menulis resensi buku dengan menggunakan model pembelajaran kooperatif tipe jigsaw kelas Kelas IXA SMP Negeri 1 Padamara dapat ditingkatkan. Peningkatan kemampuan tersebut dilakukan melalui pelaksanaan tindakan dalam dua siklus. Peningkatan proses pembelajaran peterampilan menulis resensi buku dengan menggunakan model pembelajaran kooperatif tipe jigsaw dikatakan berhasil, karena siswa setelah membaca buku tersebut merasa termotivasi bersikap bijaksana dalam mengambil keputusan, merasa pesan yang disampaikan penulis relevan dengan masa kini, dan mreasa mendapatkan pelajaran untuk bersikap lebih baik setelah membaca buku tersebut.

Dari hasil tes menulis resensi buku pengetahuan yang dilakukan siswa dengan menggunakan model pembelajaran kooperatif tipe jigsaw menunjukkan bahwa terjadi peningkatan yang signifikan pada tindakan siklus I dan II, dibandingkan dengan Pra Tindakan. Selain itu keterampilan menulis resensi buku secara klasikal sudah mencapai lebih dari Kriteria Ketuntasan Minimal (KKM) 72 dari presentase ketuntasan (KKM) yang ditetapkan sebesar minimal 75\%, yaitu mengalami peningkatan dari perbandingan pada siklus I dengan siklus II, hal ini ditunjukkan dengan siswa yang memperoleh nilai 72 mencapai ketuntasan belajar 78,1\% pada tindakan siklus I dan mencapai ketuntasan belajar 90,6\% setelah dilakukan tindakan siklus II atau terdapat 25 siswa untuk siklus I dan 29 siswa untuk siklus II yang sudah tuntas belajar dari 21 jumlah siswa. Dengan demikian dapat disimpulkan bahwa tindakan model pembelajaran kooperatif tipe jigsaw berhasil dan cocok diterapkan pada mata pelajaran Bahasa Indonesia, khususnya pada kompetensi dasar menulis resensi buku perlu dipertahankan dan dikembangkan.

Berdasarkan hasil dan temuan penelitian, pembahasan dan kesimpulan berikut peneliti menyampaikan saran-saran sebagai berikut. Salah satu faktor yang mempengaruhi peningkatan kemampuan siswa tersebut adalah keterlibatan siswa secara 
aktif dan kreatif dalam pembelajaran. Sudah saatnya para pengajar mengevaluasi cara mengajarnya dan menyadari dampaknya terhadap anak didik. Untuk menghasilkan manusia yang bisa berdamai dan bekerja sama dengan sesamanya dalam pembelajaran di sekolah. Untuk itu, kepada guru Bahasa Indonesia untuk : (a) merancang rencana pembelajaran dengan menempatkan siswa sebagai pusat aktivitas pembelajaran, (b) model pembelajaran kooperatif tipe jigsaw perlu lebih sering digunakan karena suasana positif yang timbul akan memberikan kesempatan kepada siswa untuk mencintai pelajaran dan sekolah/guru, sehingga siswa akan merasa lebih terdorong untuk belajar dan berpikir (c) guru senantiasa mempelajari teknik-teknik penerapan model pembelajaran kooperatif tipe jigsaw di kelas dan menyesuaikan dengan materi yang akan diajarkan, (d) memberikan kebebasan siswa untuk menyampaikan ide/gagasan selama pembelajaran, (e) memberikan arahan dan motivasi siswa. (f) perlu meningkatkan sarana pendukung pembelajaran terutama buku sumber. Dengan hasil penelitian ini hendaknya siswa menyadari bahwa (1) menulis resensi buku dengan menggunakan model pembelajaran kooperatif tipe jigsaw merupakan kegiatan menyampaikan ide/gagasan tentang fakta/peristiwa/kejadian yang terdiri dari beberapa tahapan, (2) menulis resensi buku akan lebih mudah jika dilakukan secara bersamasama dalam satu kelompok, (3) kegiatan menulis resensi buku pada hakekatnya adalah penyampaian ide/gagasan untuk menyusun suatu rencana berdasarkan data yang diperoleh, (4) model pembelajaran kooperatif tipe jigsaw melatih siswa untuk belajar mandiri, berorganisasi, bertanggung-jawab, dan mengemukakan pendapat.

Penelitian tindakan ini merupakan langkah awal pencarian alternatif strategi untuk memecahkan permasalahan pembelajaran menulis resensi buku dengan menggunakan model pembelajaran kooperatif tipe jigsaw di kelas IXA SMP Negeri 1 Padamara. Latar belakang dan subjek penelitiannya terbatas pada siswa Kelas IXA SMP Negeri 1 Padamara. Dengan demikian, disarankan kepada peneliti lain untuk menindaklanjuti hasil dan temuan penelitian ini dengan cara : (1) memperluas jangkauan latar dan subjek,(2) memperdalam analisis menyangkut komponenkomponen pembelajaran yang lain, dan (3) melakukan penelitian serupa dalam konteks pembelajaran menulis resensi cerpen jenis lainnya.

\section{UCAPAN TERIMA KASIH}

Peneliti menyampaikan ucapan terima kasih kepada SMP Negeri 1 Padamara atas pemberian izin untuk dapat melakukan penelitian di sekolah tersebut. Penulis juga mengucapkan terima kasih kepada tim redaksi Aksis atas saran dan masukan untuk perbaikan penulisan artikel ini. Semoga penelitian ini bermanfaat.

\section{REFERENSI}

Arikunto, S. (2010). Prosedur Penelitian, Suatu Pendekatan Praktik. Jakarta: Rineka Cipta.

Dalman. (2015). Keterampilan Menulis. Jakarta: Rajawali Pers. 
Desrina, I. (2013). Peningkatan Keterampilan Menulis Ringkasan Melalui Model Pembelajaran Kooperatif Tipe Jigsaw Siswa Kelas VIII 7 SMP Negeri 1 Batusangkar. Jurnal Bahasa, Sastra dan Pembelajaran. Retrieved from https://lib.unnes.ac.id/895/

Eanes, R. (1997) Content Area Literacy: Teaching for Today and Tomorrow. Washington D.C: Delmar Pu-blishers Inc.

Hamalik, O. (2010). Proses Belajar Mengajar. Jakarta: Bumi Aksara.

Hanif, W. A. (2010). Bahasa Indonesia untuk SMP/MTs Kelas IX.Jakarta:Pusat Kurikulum dan Perbukuan Kementerian Pendidikan Nasional.

Hertiavi, M.A., dkk. (2010). Penerapan Model Pembelajaran Kooperatif Tipe Jigsaw untuk Peningkatan Kemampuan Pemecahan Masalah Siswa SMP. Jurnal Pendidikan Fisika Indonesia 6. Retrieved from http://journal.unnes.ac.id/nju/index.php/JPFI/article/view/1104

Kusmana, S. (2014). Kreativitas Menulis. Yogyakarta: Ombak.

Kusmaniyah, S. (2012). Pengembangan Model STAD Bhineka dalam Pembelajaran Menulis Resensi Berkonteks Multikultural Bermuatan Nilai-Nilai Karakter pada Peserta Didik SMA. Seloka: Jurnal Pendidikan Bahasa dan Sastra Indonesia. Retrieved from https://journal.unnes.ac.id/sju/index.php/seloka/article/view/694/676

Kusmayati, N.B., Mulyati, Y., Damaianti, V. S., \& Sastromiharjo, A. (2019). Teaching of Social Culture-Based Critical Literation for University Students. Aksis: Jurnal Pendidikan Bahasa dan Sastra Indonesia 2(1). 118-134. doi: doi.org/10.21009/AKSIS.030104

Purwahida, R. (2017). Interaksi sosial pada kumpulan cerpen Potongan Cerita di Kartu Pos karangan Agus Noor dan implikasinya terhadap pembelajaran sastra di SMA. Aksis: Jurnal Pendidikan Bahasa dan Sastra Indonesia 1(1). 118-134. doi: doi.org/10.21009/AKSIS.010107

Purwahida, R. (2018). Problematika Pengembangan Modul Pembelajaran Baca Tulis Anak Usia Sekolah Dasar. Aksis: Jurnal Pendidikan Bahasa dan Sastra Indonesia 2(1). 118-134. doi: doi.org/10.21009/AKSIS.020108

Samad, D. (1997). Dasar-dasar Meresensi Buku. Jakarta: Grasindo.

Soffalina, Y. (2010). Peningkatan Keterampilan Menulis Resensi Buku dengan Menggunakan Model Pembelajaran Kooperatif Tipe Jigsaw pada Siswa Kelas XI. IPA-1 SMA Muhammadiyah 1 Surakarta Tahun Ajaran 2009/ 2010. Retrieved from http://eprints.ums.ac.id/8439/1/A310060057.pdf 
Wahyuningsih, S. (2017). Pengaruh Pembelajaran Kooperatif Jigsaw dan Motivasi Belajar Terhadap Hasil Belajar Memahami Paragraf. Lingua Fanca: Jurnal Bahasa, Sastra, dan Pengajarannya. Retrieved from http://journal.umsurabaya.ac.id/index.php/lingua/article/view/563/451 